\title{
Evaluation of the Pharmacokinetic Interaction between Candesartan Cilexetil and Felodipine
}

Eduardo Abib Junior ${ }^{1,2 *}$, Luciana Fernandes Duarte ${ }^{2}$, Luciana Oliveira ${ }^{3}$, Fabio Proença Barros ${ }^{4}$

${ }^{1}$ Department of Clinical Medicine, Faculty of Medical Sciences, State University of Campinas (UNICAMP), 13083-970, Campinas, SP, Brazil ${ }^{2}$ Scentryphar Clinical Research, 13020-420, Campinas, SP, Brazil

${ }^{3}$ AstraZeneca, 06707-000, Cotia, SP, Brazil

${ }^{4}$ Core Clinical Research, 12914-160, Bragança Paulista, SP, Brazil

\begin{abstract}
The study was performed to evaluate the pharmacokinetic interaction of test formulation of candesartan $16 \mathrm{mg}$ tablet and felodipine extended release $5 \mathrm{mg}$ tablet together in a combination package, comparing with the fasting period intake of commercial formulations of both $A$ tacand $\AA 16 \mathrm{mg}$ tablet and Splendil $\circledast$ extended release $5 \mathrm{mg}$ tablet (Test formulation and reference formulation from AstraZeneca, Brazil) in 36 volunteers of both sexes. The study was conducted open with randomized three period crossover design and a one week wash out period. The candesartan and felodipine were analyzed by LC-MS-MS. The mean ratio of parameters $\mathrm{C}_{\max }$ and $\mathrm{AUC}_{0-\mathrm{t}}$ and $90 \%$ confidence intervals of correspondents were calculated to determine the pharmacokinetic interaction. Geometric mean of candesartan exposure together in a combination package felodipine individual percent ratio was $102.51 \%$ $\mathrm{AUC}_{0 . \mathrm{t}}$ and $110.40 \%$ for $\mathrm{C}_{\max }$. The $90 \%$ confidence intervals were $90.00-116.77 \%$ and $93.94-129.74 \%$, respectively. Geometric mean of felodipine exposure together in a combination package candesartan individual percent ratio was $102.69 \% \mathrm{AUC}_{0 . t}$ and $96.17 \%$ for $\mathrm{C}_{\max }$. The $90 \%$ confidence intervals were $89.46-117.88 \%$ and $82.07-112.69 \%$, respectively. The major variable in this respect, AUC, was not signicantly affected by felodipine and candesartan with concomitant administration. The $\mathrm{Cmax}$ of candesartan was not signicantly affected by co-administration of felodipine. Based on these data and in presence in the market of isolated candersatana and felodipino formularizations used in combination in medical practice, it is concluded that there are no risk with concomitant administration between felodipine and candesartan.
\end{abstract}

Keywords: Candesartan; Felodipine; Biological availability; Pharmacokinetics; Chromatography; Bioequivalence

\section{Introduction}

Angiotensin II receptor antagonists have been thought to provide potential advantages over angiotensin converting enzyme inhibitors (ACEIs). One of the advantages is their high specificity in blocking the effects of circulating and tissue angiotensin II at the AT1 receptor level [20]. ACEIs prevent the enzymatic cleavage of angiotensin I and thus the formation of angiotensin II. They have been proven to be effective in the treatment of hypertension or heart failure. However, in addition to blocking renin-angiotensin system ACEIs increase the levels of other substrates of ACE, including bradykinin that produces dry cough [45]. Thus, AT1 receptor antagonists can be used to replace ACEIs in patients who do not tolerate them and suffer from cough or angioedema. The angiotensin-converting enzyme (ACE) converts the inactive decapeptide angiotensin I to angiotensin II. The discovery of specific angiotensin II receptor antagonists led to the identification of various subtypes of angiotensin II receptors [48]. Candesartan cilexetil has been developed at with the aim of identifying a nonpeptide angiotensin II receptor antagonist with a longlasting and insurmountable effect [32]. It is administered orally as candesartan cilexetil, which is completely converted during enteric absorption to the active compound, candesartan [44]. Candesartan cilexetil, is rapidly and completely hydrolysed to the active compound candesartan during absorption from the gastrointestinal tract. Candesartan is a potent, long-acting, selective angiotensin II AT, receptor blocker which is well-toleratod and effective with a once-daily dosing regimen in hypertensive patients [26].

The pharmacokinetics of candesartan cilexetil have not been investigated in patients $<18$ years of age. The pharmacokinetics of candesartan have been studied in the elderly ( $\geq 65$ years). The plasma concentration of candesartan was higher in the elderly $\left(\mathrm{C}_{\max }\right.$ was approximately 50\% higher, and AUC was approximately $80 \%$ higher) compared to younger subjects administered the same dose. The pharmacokinetics of candesartan were linear in the elderly, and candesartan and its inactive metabolite did not accumulate in the serum of these subjects upon repeated, once-daily administration. There is no difference in the pharmacokinetics of candesartan between male and female subjects. In hypertensive patients with renal insufficiency, serum concentrations of candesartan were elevated. After repeated dosing, the AUC and Cmax were approximately doubled in patients with severe renal impairment (creatinine clearance $<30 \mathrm{~mL}$ / $\mathrm{min} / 1.73 \mathrm{~m} 2$ ) compared to patients with normal kidney function. The pharmacokinetics of candesartan in hypertensive patients undergoing hemodialysis are similar to those in hypertensive patients with severe renal impairment. Candesartan cannot be removed by hemodialysis. No initial dosage adjustment is necessary in patients with renal insufficiency. Thiazide diuretics are eliminated by the kidney, with a terminal half-life of 5-15 hours. In a study of patients with impaired renal function (mean creatinine clearance of $19 \mathrm{~mL} / \mathrm{min}$ ), the half-life of hydrochlorothiazide elimination was lengthened to 21 hours. The pharmacokinetics of candesartan were compared in patients with mild

*Corresponding author: Eduardo Abib Junior, Scentryphar Clinical Research, 885, Barão de Itapura ave, Campinas, SP - Brazil 13020-420, Tel: (19) 3232-6350 Fax: (19) 3231-6715; E-mail: eabib@scentryphar.com

Received January 04, 2011; Accepted January 25, 2011; Published February 01, 2011

Citation: Abib Jr E, Duarte LF, Oliveira L, Barros FP (2011) Evaluation of the Pharmacokinetic Interaction between Candesartan Cilexetil and Felodipine. J Bioequiv Availab 3: 005-010. doi:10.4172/jbb.1000049

Copyright: (C) $2011 \mathrm{Abib} J \mathrm{E}$, et al. This is an open-access article distributed under the terms of the Creative Commons Attribution License, which permits unrestricted use, distribution, and reproduction in any medium, provided the original author and source are credited. 
(Child-Pugh A) or moderate (Child-Pugh B) hepatic impairment to matched healthy volunteers following a single dose of $16 \mathrm{mg}$ candesartan cilexetil. The AUC for candesartan in patients with mild and moderate hepatic impairment was increased $30 \%$ and $145 \%$ respectively. The Cmax for candesartan was increased $56 \%$ and $73 \%$ respectively. The pharmacokinetics of candesartan in severe hepatic impairment have not been studied. No dose adjustment is recommended for patients with mild hepatic impairment. In patients with moderate hepatic impairment, consideration should be given to initiation of candesartan at a lower dose, such as $8 \mathrm{mg}$. If a lower starting dose is selected for candesartan cilexetil, is not recommended for initial titration because the appropriate initial starting dose of candesartan cilexetil cannot be given [8].

Felodipine is a calcium antagonist, within the dihydropyridine group, which lowers blood pressure by a selective action on the vascular smooth muscle in the resistance vessels $[1,49,51,53]$. Being a dihydropyridine derivative felodipine has the advantage of being more selective as vasodilator and having less cardiac effects than non-dihydropyridine calcium antagonists $[15,47,52]$. This benefit is abolished by the poor bioavailability of the drug, which-although being almost completely absorbed from the gastrointestinal tract-is only $15 \%$ bioavailable after oral administration [5]. The poor oral bioavailability of felodipine was attributable to its extensive first-pass metabolism and the very low water solubility of the drug [40]. Treatment with felodipine reduces arterial blood pressure by reducing systemic vascular resistance [24]. Felodipine is used in the treatment of all forms of hypertension and in prophylactic treatment of angina pectoris [27, 42]. There is a close relationship between the felodipine concentration in plasma and the lowering of blood pressure. More sustained plasma concentrations might thus produce a more even effect on blood pressure, minimize concentration dependent side effects and at the same time increase the duration of effect $[2,3]$.

Plasma concentrations of felodipine, after a single dose and at steady state, increase with age. Mean clearance of felodipine in elderly hypertensives (mean age 74) was only $45 \%$ of that of young volunteers (mean age 26). At steady state mean AUC for young patients was $39 \%$ of that for the elderly. Data for intermediate age ranges suggest that the AUCs fall between the extremes of the young and the elderly. In patients with hepatic disease, the clearance of felodipine was reduced to about $60 \%$ of that seen in normal young volunteers. Renal impairment does not alter the plasma concentration profile of felodipine; although higher concentrations of the metabolites are present in the plasma due to decreased urinary excretion, these are inactive $[6,12]$.

Few studies of the combination of candesartan and other types of antihypertensive drugs, such as calcium antagonists, have been reported [25]. The objective of this study was to evaluate the pharmacokinetic interaction of test formulation of candesartan $16 \mathrm{mg}$ tablet and felodipine extended release $5 \mathrm{mg}$ tablet together in a combination package, comparing with the fasting period intake of commercial formulations of both Atacand ${ }^{\odot} 16 \mathrm{mg}$ tablet and Splendil ${ }^{\triangleright}$ extended release $5 \mathrm{mg}$ tablet (Test formulation and reference formulation from AstraZeneca, Brazil).

\section{Methods}

\section{Study protocol}

The study was performed in accordance with the Helsinki Declaration and Good Clinical Practice Guideline, and informed consent was obtained from participants prior to study commencement. The clinical part of the study was condueted at Scentryphar Clinical
Research (Campinas City, São Paulo, Brazil) and the bioanalytical part at Core Clinical Research (Bragança Paulista, São Paulo, Brazil).

\section{Subjects}

Thirty six healthy volunteers of both sexes (18 males and 18 females) who were between the ages of 18 and 49 (mean \pm SEM: 30.83 \pm 9.26 years), who had heights between $148.0 \mathrm{~cm}$ and $182.0 \mathrm{~cm}(166.0$ $\pm 0.10 \mathrm{~cm})$, and who weighed between $47.60 \mathrm{~kg}$ and $83.50 \mathrm{~kg}(65.55 \pm$ $9.94 \mathrm{~kg}$ ) and within $15 \%$ of their ideal body weight were enrolled in the study. Subjects were judged eligible for enrolment in this study if they were in compliance with all the inclusion and exclusion criteria described in the protocol.

All the subjects provided written informed consent to participate after explaining the nature and purpose of the study. The study protocol was approved by the University of Campinas/Unicamp with the ethical principles described in the Declaration of Helsinki, guidelines for International Conference on Harmonization-Good clinical practices (ICH-GCP).

All volunteers were healthy as assessed by physical examination, ECG, and the following laboratory tests: blood glucose, urea, creatinine, AST, ALT, alkaline phosphatase, Gamma GT, total bilirrubin, albumin and total protein, triglycerides, total cholesterol, hemoglobin, hematocrit, total and differential white cell counts and routine urine. All subjects were negative for HIV, HBV (except for serological scare) and $\mathrm{HCV}$.

\section{Drug products}

The test formulation employed was Candesartan $16 \mathrm{mg}$ tablet and Felodipine extended release $5 \mathrm{mg}$ tablet (lot number 81234/81211) and the reference formulation was: Atacand ${ }^{\circ} 16 \mathrm{mg}$ tablet (lot number 81234) and Splendil ${ }^{\circ}$ extended release $5 \mathrm{mg}$ tablet (lot number 81211).

\section{Study design}

The study was performed to evaluate the pharmacokinetic interaction of test formulation of candesartan $16 \mathrm{mg}$ tablet and felodipine extended release $5 \mathrm{mg}$ tablet together in a combination package, comparing with the fasting period intake of commercial formulations of both Atacand ${ }^{\star} 16 \mathrm{mg}$ tablet and Splendil ${ }^{\bullet}$ extended release $5 \mathrm{mg}$ tablet (Test formulation and reference formulation from AstraZeneca, Brazil).

The study was conducted in an open label trial, crossover assignment, single-arm pharmacokinetics study, in wich healthy volunteers received 3 treatments in 6 sequences and in 3 periods (Williams' Plan) with a 1 week wash out period between the doses. Candesartan was supplied in $16 \mathrm{mg}$ simple tablets together with felodipine, in an extended release 5 $\mathrm{mg}$ tablet or one $16 \mathrm{mg}$ simple tablet of Atacand ${ }^{\circledR}$ together with Splendil ${ }^{\circ}$, extended release $5 \mathrm{mg}$ tablet, according to the aleatorization plan. Tablets were given to healthy volunteers with $200 \mathrm{~mL}$ of pure mineral non-sparkling water. All volunteers were then fasted 05 hours following the drug administration, after which a standard lunch was consumed and an evening meal was provided 10 hours after dosing. No other food was permitted during the "in-house" period. Liquid consumption was permitted ad libitum after lunch but xanthine-containing drinks including tea, coffee and cola were avoided. Systolic and Diastolic arterial pressure, heart rate and temperature were recorded just before and hourly after drug administration.

Blood samples $(06 \mathrm{~mL})$ from a suitable antecubital vein were collected into EDTA containing tubes before and 0.30, 1.00, 1.30, 2.00, $2.30,3.00,3.30,4.00,4.30,5.00,6.00,8.00,10.00,12.00,20.00,24.00$ 
36.00, 48.00 hours post-dosing for candesartan and 1.00, 2.00, 2.30, $3.00,3.30,4.00,4.30,5.00,5.30,6.00,7.00,8.00,10.0,12.0,20.00,24.00$, $36.00,48.00$ hours post-dosing for felodipine.

\section{Drug analysis}

Blood samples were cooled in an bath and centrifuged at $3.000 \mathrm{rpm}$ for at least $10 \mathrm{~min}$ at approximately $4^{\circ} \mathrm{C}$. At least $3 \mathrm{~mL}$ of plasma were dispensed into polypropylene tubes. Sample tubes were frozen at $-70^{\circ} \mathrm{C}$ As amostras de: Os as suntos incl, and maintained to that temperature until analysis. All samples from a single volunteer were analyzed on the same day in order to avoid interassay variation.

Candesartan and felodipine were extracted from human plasma by simple and single step liquid-liquid. Plasma concentrations of candesartan was determined by the HPLC coupled with tandem mass spectrometry (LC/MS/MS), using losartan as internal standard (IS). Both the compounds were tuned in positive mode for multiple reaction monitoring (MRM). In MRM mode, $439.51 \rightarrow 309.50$ and $421.37 \rightarrow 179.04$ were selected as transition ions for candesartan and IS, respectively. Plasma concentrations of felodipine was determined by the HPLC coupled with tandem mass spectrometry (LC/MS/MS), using nimodipine as internal standard (IS). Both the compounds were tuned in positive mode for multiple reaction monitoring (MRM). In MRM mode, $382.20 \rightarrow 144.75$ and $417.00 \rightarrow 121.00$ were selected as transition ions for felodipine and IS, respectively.

\section{Method validation}

Quantitation was based on determination of relationship between candesartan/ felodipine peaks areas and I.S. peaks areas. Selectivity was evaluated by extracting plasma samples of plasma from six different volunteers, including a lipemic and hemolysed plasma. Recoveries of candesartan/ felodipine at the three QC concentrations and I.S. were determined by comparing peak areas of spiked plasma samples with the peak area in solutions prepared with the same nominal concentration. For precision (as relative standard deviation, R.S.D.) and accuracy (as relative error, R.E.) studies, samples were prepared at three QC and were analysed in the same day (intraday precision and accuracy), and analysed in 3 consecutive days (inter-day precision and accuracy).

The calibration range of was $2.00-500.00 \mathrm{ng} / \mathrm{mL}$ (candesartan) and $0.05-4.00 \mathrm{ng} / \mathrm{mL}$ (felodipine). The validated method linearity $>0,98$.

The method was validated according to ANVISA (National Health Surveillance Agency of Brazilian Government) criteria and used to determine the concentration of candesartan/ felodipine in volunteers plasma.

\section{Pharmacokinetic analysis and statistical analysis}

The first-order terminal elimination rate constant $(\mathrm{Ke})$ was estimated by linear regression from the points describing the elimination phase on a log-linear plot, using the software SAS ${ }^{\oplus}$ Institute (Version 9.1.3). Elimination half-life $\left(\mathrm{T}_{1 / 2}\right)$ was derived from this rate constant $\left(\mathrm{T}_{1 / 2}=\ln \right.$ $(2) / \mathrm{Ke})$. The maximum observed plasma concentration $\left(\mathrm{C}_{\max }\right)$ and the time taken to achieve this concentration $\left(\mathrm{T}_{\max }\right)$ were obtained directly from the curves. The areas under the candesartan/felodipine plasma concentration versus time curves from 0 to 48 hours $\left(\mathrm{AUC}_{0-48 \mathrm{~h}}\right)$ were calculated by applying the linear trapezoidal rule. Extrapolation of these areas to infinity ( $\mathrm{AUC}_{0-\infty}$ ) was done by adding the value $\mathrm{C} 48 / \mathrm{Ke}$ to the calculated $\mathrm{AUC}_{0-48 \mathrm{~h}}$ (where $\mathrm{C} 48=$ plasma concentration calculated from the log-linear regression equation obtained for the estimation of Ke 48 hours after dose).

The bioequivalence between both formulations was assessed by calculating individual $\mathrm{C}_{\max }, \mathrm{AUC}_{0-48 \mathrm{~h}}, \mathrm{AUC}_{0-\infty}$ and $\mathrm{C}_{\max } / \mathrm{AUC}_{0-48 \mathrm{~h}}$ ratios (test/reference) together with their mean and $90 \%$ confidence intervals (CI) after log transformation of the data. The inclusion of the $90 \% \mathrm{CI}$ for the ratio in the $80 \%$ to $125 \%$ range was analyzed by nonparametric (SAS ${ }^{\oplus}$ Institute Version 9.1.3) and parametric (ANOVA) methods.

\section{Results}

\section{Tolerability analysis}

Candesartan and felodipine was well tolerated at the administered dose. All the biochemical parameters did not any clinical relevant alterations. No adverse effects serious were either reported or observed.

\section{Pharmacokinetic and statistical analysis}

The mean $( \pm$ SD) plasma concentration-time profiles are presented in Figure 1 (candesartan) and Figure 2 (felodipine) and the pharmacokinetic parameters of both substances are summarized in Table 1 and Table 2.

The mean of $\mathrm{C}_{\max }$ of candesartan was $148.24 \mathrm{ng} / \mathrm{mL}$ in reference product and $158.36 \mathrm{ng} / \mathrm{mL}$ in test product. Both occurred $4.50 \mathrm{~h}$ after application. $\mathrm{C}_{\max }$ of felodipine was on average $1.57 \mathrm{ng} / \mathrm{mL}$ in reference product and $1.45 \mathrm{ng} / \mathrm{mL}$ in test product and occurred 4.00 $\mathrm{h}$ after administration (reference) and $5.50 \mathrm{~h}$ (test). For candesartan,

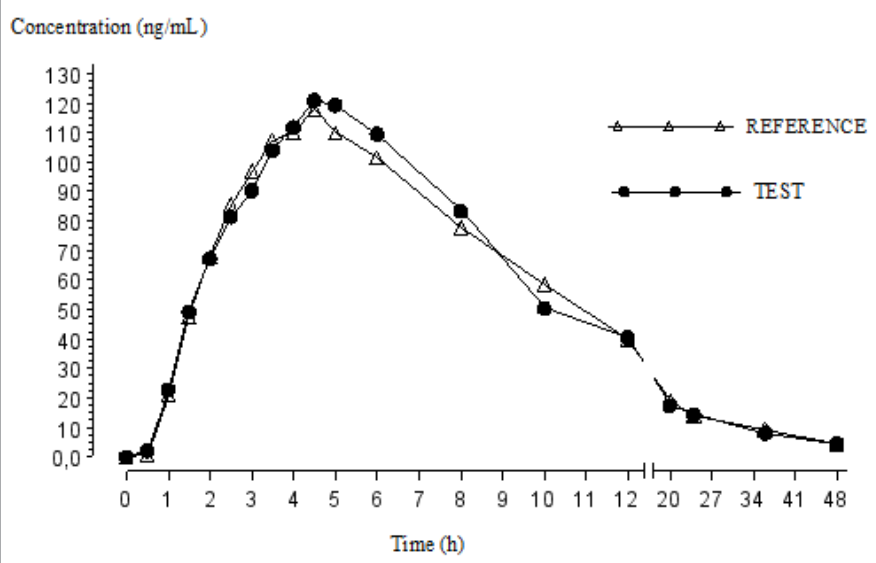

Figure 1: Mean plasma concentration-time profile of candesartan over the firs $48 \mathrm{~h}$ after oral administration of the test and reference formulation.

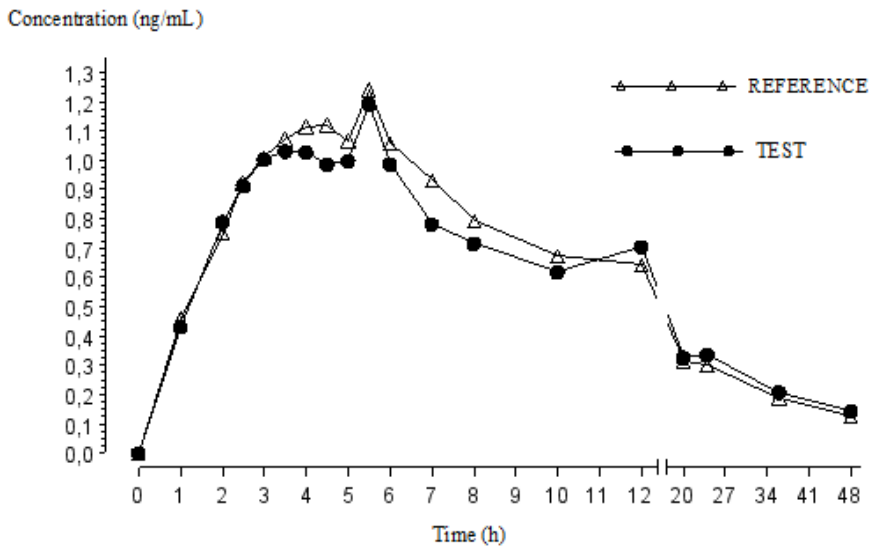

Figure 2: Mean plasma concentration-time profile of felodipine over the first 48 $\mathrm{h}$ after oral administration of the test and reference formulation. 


\begin{tabular}{|c|c|c|c|c|c|c|c|c|}
\hline \multirow[b]{3}{*}{ Parameter (unit) } & \multicolumn{3}{|c|}{ CANDESARTAN } & & \multicolumn{4}{|c|}{ FELODIPINE } \\
\hline & \multicolumn{2}{|r|}{ TEST } & \multicolumn{2}{|c|}{ REFERENCE } & \multicolumn{2}{|r|}{ TEST } & \multicolumn{2}{|c|}{ REFERENCE } \\
\hline & $\begin{array}{l}\text { Means } \\
\text { (Median) }\end{array}$ & $\begin{array}{l}\text { Standard Deviation } \\
\text { (Amplitude) }\end{array}$ & Means (Median) & $\begin{array}{l}\text { Standard Deviation } \\
\text { (Amplitude) }\end{array}$ & $\begin{array}{l}\text { Means } \\
\text { (Median) }\end{array}$ & $\begin{array}{l}\text { Standard Deviation } \\
\text { (Amplitude) }\end{array}$ & $\begin{array}{l}\text { Means } \\
\text { (Median) }\end{array}$ & $\begin{array}{l}\text { Standard Deviation } \\
\text { (Amplitude) }\end{array}$ \\
\hline $\mathrm{AUC}_{0-\mathrm{t}}(\mathrm{ng} \cdot \mathrm{h} / \mathrm{mL})$ & 1392.01 & 505.99 & 1389.61 & 570.63 & 19.73 & 8.99 & 19.38 & 10.00 \\
\hline $\mathrm{AUC}_{0-\text { inf }}(\mathrm{ng} \cdot \mathrm{h} / \mathrm{mL})$ & 1509.70 & 535.46 & 1502.12 & 617.18 & 24.41 & 10.78 & 23.06 & 13.14 \\
\hline $\mathrm{C}_{\max }(\mathrm{ng} \cdot \mathrm{h} / \mathrm{mL})$ & 158.36 & 60.97 & 148.24 & 66.21 & 1.45 & 0.64 & 1.57 & 0.89 \\
\hline $\mathrm{T}_{\max }($ median/amp) (h) & 4.50 & 6.50 & 4.50 & 8.00 & 5.50 & 10.00 & 4.00 & 10.00 \\
\hline $\operatorname{Kel}(1 / \mathrm{h})$ & 0.05 & 0.02 & 0.06 & 0.02 & 0.04 & 0.02 & 0.04 & 0.01 \\
\hline $\mathrm{T}_{1 / 2}($ median/amp) $(\mathrm{h})$ & 14.29 & 24.02 & 11.26 & 30.39 & 17.16 & 36.11 & 15.67 & 27.22 \\
\hline
\end{tabular}

Table 1: Mean pharmacokinetic parameters of candesartan and felodipine of test and reference formulation.

\begin{tabular}{|c|c|c|c|c|}
\hline & \multicolumn{2}{|c|}{ CANDESARTAN } & \multicolumn{2}{|c|}{ FELODIPINE } \\
\hline & \multicolumn{2}{|c|}{ TEST REFERENCE } & \multicolumn{2}{|c|}{ TEST REFERENCE } \\
\hline Parameter (unit) & Geometric Mean & Geometric Mean & Geometric Mean & Geometric Mean \\
\hline $\mathrm{AUC}_{\mathrm{o}-\mathrm{t}}(\mathrm{ng} \cdot \mathrm{h} / \mathrm{mL})$ & 1311.45 & 1279.29 & 17.72 & 17.26 \\
\hline$A \cup C_{\text {o-inf }}^{0-1}(\mathrm{ng} \cdot \mathrm{h} / \mathrm{mL})$ & 1425.50 & 1382.84 & 22.12 & 20.56 \\
\hline $\mathrm{C}_{\max }(\mathrm{ng} / \mathrm{mL})$ & 147.32 & 133.45 & 1.30 & 1.35 \\
\hline
\end{tabular}

Table 2: Geometric mean parameters of candesartan and felodipine of test and reference formulation.

\begin{tabular}{|c|c|c|c|c|c|c|c|c|c|c|}
\hline \multirow[b]{2}{*}{ Parameter } & \multicolumn{5}{|c|}{ CANDESARTAN } & \multicolumn{5}{|c|}{ FELODIPINE } \\
\hline & Ratio T/R (\%) & Lower Limit & Upper Limit & Power (\%) & Coefficient of Variation & Ratio T/R (\%) & Lower Limit & Upper Limit & Power (\%) & $\begin{array}{l}\text { Coefficient of } \\
\text { Variation }\end{array}$ \\
\hline $\mathrm{AUC}_{\text {o-t }}$ & 102.51 & 90.00 & 116.77 & 72.81 & 32.46 & 102.69 & 89.46 & 117.88 & 99.99 & 34.46 \\
\hline$A \cup C_{\text {o-inf }}^{0-t}$ & 103.09 & 91.12 & 116.62 & 77.35 & 30.68 & 107.55 & 94.13 & 112.87 & 99.99 & 32.21 \\
\hline $\mathrm{C}_{\max }$ & 110.40 & 93.94 & 129.74 & 29.50 & 40.81 & 96.17 & 82.07 & 112.69 & 99.99 & 39.95 \\
\hline$T_{\max }(\operatorname{dif})(h)$ & -0.50 & -1.00 & 0.50 & - & - & -0.50 & -2.00 & 0.50 & - & - \\
\hline
\end{tabular}

Table 3: Ratios mean and the $90 \%$ geometric confidence interval of test and reference formulation.

the geometric means of $\mathrm{AUC}_{0-\infty}$ as a measure of extent of absorption amount to 1502.12 ng.h $/ \mathrm{mL}$ (reference) and 1509.70 ng.h $/ \mathrm{mL}$ (test). The geometric means of $\mathrm{AUC}_{0-\infty}$ of felodipine are $23.06 \mathrm{ng} . \mathrm{h} /$ $\mathrm{mL}$ (reference) and $24.41 \mathrm{ng} . \mathrm{h} / \mathrm{mL}$ (test). The values of $\mathrm{AUC}_{0 \mathrm{t}}$ for candesartan are $1389.61 \mathrm{ng} . \mathrm{h} / \mathrm{mL}$ (reference) and $1392.01 \mathrm{ng} . \mathrm{h} / \mathrm{mL}$ (test). In the felodipine evaluation the amounts of $\mathrm{AUC}_{0-\mathrm{t}}$ are $19.38 \mathrm{ng} . \mathrm{h} /$ $\mathrm{mL}$ (reference) and $19.73 \mathrm{ng} . \mathrm{h} / \mathrm{mL}$ (test). No significant differences with respect to drug absorption were found. Elimination half-lives and elimination rate constancy were well comparable between the different preparations.

The resulting $90 \%$ confidence intervals of the parameter ratios for for $\mathrm{AUC}_{0-\infty}, \mathrm{AUC}_{0-\mathrm{t}}$ and $\mathrm{C}_{\max }$ as well as for differences in $\mathrm{t}_{\max }$ are summarized in Table 03 .

\section{Discussion}

Over the past few decades, reducing blood pressure in patients with hypertension has been shown to decrease the risk for cardiovascular accident, chronic renal failure, and the overall morbidity and mortality of cardiovascular disease [13]. However, first-line antihypertensive monotherapy is effective in reducing blood pressure to the normal range in $60 \%$ of patients, leaving the remainder with inadequately controlled hypertension and at continued risk. For these patients, combination therapy usually results in better blood pressure control. Furthermore, increasing the dose of most antihypertensive agents used as monotherapy results in limited efficacy and poorer tolerability [41]. Combination therapy produced significantly greater decreases in blood pressure than either medication alone, which suggests a clinical additive effect of these 2 drugs. Furthermore, combination therapy was associated with a lower incidence of adverse effects than either monotherapy. An alternative strategy for improving blood pressure control is to combine 2 or more drugs with different but complementary mechanisms of action. Combination therapy (at lower doses of each drug) may result in fewer adverse effects and enhanced patient efficacy plus compliance $[17,50]$. Normalization of blood pressure has been achieved in up to $80 \%$ of patients treated with different combination therapies [11,
22, 30, 31]. Combinations include a beta-blocker or an angiotensinconverting enzyme inhibitor with a diuretic, and a beta-blocker with an alpha-blocker $[18,19,23,33,35,38]$. Calcium antagonists used in combination with beta-blockers, diuretics, angiotensin-converting enzyme inhibitors, and even with other types of calcium antagonists, also have been reported $[4,7,10,16,28,29,39,43,46]$.

Candesartan is a highly potent and long-acting selective angiotensin 1- receptor blocker. The antihypertensive effects of candesartan alone or combined with a diuretic have been assessed in several studies $[9,14,21,34]$. However, few studies of the combination of candesartan and other types of antihypertensive drugs, such as calcium antagonists, have been reported. When it was used in combination therapy, hydrochlorothiazide was recommended. Combination of candesartan and felodipine is an effective alternative therapy for the treatment of hypertension. It can be used when patients cannot tolerate the adverse effects of hydrochlorothiazide [36,37].

The purpose of the present study was to develop and validate an LC-MS-MS method with simple sample preparation to determine pharmacokinetic interaction of formulation of candesartan and felodipine in 36 healthy volunteers. A rapid, sensitive and reliable LC/ MS/MS method for the determination of candesartan and felodipine in human plasma has been successfully developed and validated using liquid-liquid extraction as sample preparation procedure. This assay method demonstrated acceptable sensitivity, precision, accuracy, selectivity, recovery and stability, and less absolute and relative matrix effect. The validated method was successfully applied to assay human plasma samples from the pharmacokinetic interaction study of candesartan and felodipine.

In this study combination of candesartan and felodipine was evaluated. The mean ratio of parameters $\mathrm{C}_{\max }$ and $\mathrm{AUC}_{0-\mathrm{t}}$ and $90 \%$ confidence intervals of correspondents were calculated to determine the pharmacokinetic interaction. The point estimator and the $90 \%$ confidence intervals for the $\mathrm{AUC}_{0-\mathrm{t}}$ ratio (test/reference: $102.51 \%$ $[90.00 \%-116.77 \%])$ indicate high similarity of both formulations 
Citation: Abib Jr E, Duarte LF, Oliveira L, Barros FP (2011) Evaluation of the Pharmacokinetic Interaction between Candesartan Cilexetil and Felodipine. J Bioequiv Availab 3: 005-010. doi:10.4172/jbb.1000049

with respect to the extent of candesartan exposure together in a combination package felodipine. Similarity not was also observed for $90 \%$ confidence intervals for the $\mathrm{C}_{\max }$ ratio (test/reference: $110.40 \%$ [93.94\% - 129.74\%]) indicating pharmacokinetic interaction candesartan together in a combination package felodipine. Regarding the $\mathrm{AUC}_{0-\mathrm{t}}$ ratio of felodipine, the point estimator is $102.69 \%$ and the $90 \%$ confidence interval $89.46 \%$ - $117.88 \%$. Furthermore, not felodipine pharmacokinetic interaction together in a combination package candesartan is observed the point estimator and $90 \%$ confidence of $\mathrm{C}_{\mathrm{max}}$ of this active agent $(96.17 \%$ [82.07\% - 112.69\%]).

The major variable in this respect, AUC, was not signicantly affected by felodipine and candesartan with concomitant administration. The Cmax of candesartan was not signicantly affected by co-administration of felodipine, whereas increase of only $10 \mathrm{ng} / \mathrm{mL} \pm 12 \mathrm{ng} / \mathrm{mL}$ Cmax was found. Based on these data and in presence in the market of isolated candersatana and felodipino formularizations used in combination in medical practice, it is concluded that there are no risk with concomitant administration between felodipine and candesartan.

\section{Acknowledgments}

This research work is financially supported by the Scentryphar Clinical Research, Brazil.

\section{References}

1. Blyckert E, Wingstrand K, Edgar B, Lidman K (1990) Plasma concentration profiles $\AA$ and antihypertensive effect of conventional and extended release felodipine tablets. Br J Clin Pharmacol 29: 39-45.

2. Blychert E, Edgar B, Elmfeldt D, Hedner T (1991) A population study of the pharmacokinetics of felodipine. Blood Press 31: 15-24.

3. Blychert E (1992) Felodipine pharmacokinetics and plasma concentration vs effect relationships. Blood Press 2: 1-30.

4. Dahlo"f B, Andersson OK (1995) A felodipine-metoprolol extended-release tablet: Its properties and clinical development. J Hum Hypertens 9: 43-47.

5. Dunselman PH, Edgar B (1991) Felodipine clinical pharmacokinetics. Clin Pharmacokinet 21: 418-430.

6. Edgar B, Regardh C, Lundborg G, Romare PS, Nyberg G (1987) Pharmacokinetics and pharmacodynamic studies of felodipine in healthy subjects after various single, oral and intravenous doses. Biopharm. Drug Dispos 8: 235-248.

7. Eriksson M, Nyberg G, Lidman K, Olofsson B, Bergstrand R, et al. (1993) Aiming for steady 24-hour plasma concentrations: A comparison of two calcium antagonist and beta-blocker combinations. Blood Press Suppl 1: 16-21.

8. Gleiter $\mathrm{CH}$, Morike KE (2002) Clinical pharmacokinetics of candesartan. Clin Pharmacokinet 41: 07-17

9. Gradman AH, Lewin A, Bowling BT, Tonkon M, Deedwania PC, et al. (1999) For the Candesartan Versus Losartan Eficacy Comparison (CANDLE) Study Group. Comparative effects of candesartan cilexetil and losartan in patients with systemic hypertension. Heart Dis 1: 52-57.

10. Hallin L, Andren L, Hansson L (1983) Controlled trial of nifedipine and bendroflumethiazide in hypertension. J Cardiovasc Pharmacol 5: 1083-1085.

11. Hansson L, Zanchetti A, Carruthers SG, Dahl FB, Elmfeldt D, et al. (1998) Effects of intensive blood-pressure lowering and low-dose aspirin in patients with hypertension: Principal results of the Hypertension Optimal Treatment (HOT) randomized trial. Lancet 351: 1755-1762.

12. Hedner T, Sjogren E, Elmfeldt D (1987) Antihypertensive effects and pharmacokinetics of felodipine combined with a ,-blocker and, a diuretic. J Cardiovasc Pharmac 10: S177-S184.

13. Ikechi GO, Brian LR (2010) Update on the role of candesartan in the optimal management of hypertension and cardiovascular risk reduction. Integrated Blood Pressure Control 3: 45-55. Comparison of Candesartan

14. Kloner RA, Weinberger M, Pool JL, Chrysant S, Prasad R, et al. (2001) For the Comparison of Candesartan and Amlodipine for Safety, Tolerability and Eficacy
(CASTLE) Study Investigators. Comparative effects of candesartan cilexetil and amlodipine in patients with mild systemic hypertension. Am J Cardiol 87: 727-731.

15. Little WC, Cheng CP, Elvelin L, Nordlander M (1995) Vascular selective calcium entry blockers in the treatment of cardiovascuolar disorders: focus on felodipine. Cardiovasc Drugs Ther 9: 657-663.

16. MacCarthy EP (1987) Dihydropyridines and beta-adrenoceptor antagonists as combination treatment in hypertension. J Hypertens Suppl 5: 133-137.

17. MacConnachie AM, Maclean D (1995) Low dose combination antihypertensive therapy: Additional efficacy without additional adverse effects. Drug Saf 12: 85 90.

18. Mann SJ, Gerber LM (2001) Low-dose alpha/beta blockade in the treatment of essential hypertension. Am J Hypertens 14: 553-558.

19. Matheson AJ, Cheer SM, Goa KL (2001) Perindopril/indapamide $2 / 0.625 \mathrm{mg} /$ day: A review of its place in the management of hypertension. Drugs 61: 1211 1229.

20. McFayden RJ, Reid JL (1994) Angiotensin receptor antagonists as a treatment for hypertension. J Hypertens 12: 1333-1338.

21. Melian EB, Jarvis B (2002) Candesartan cilexetil plus hydrochlorothiazide combination: A review of its use in hypertension. Drugs 62: 787-816

22. Messerli FH (1992) Combination therapy in hypertension. J HumHypertens 6 : $19-21$

23. Messerli FH, Chander K (2000) Cardiac effects of combination therapy in hypertension. J Cardiovasc Pharmacol 35: 17-22.

24. Michalewicz L, Messerli FH (1997) Cardiac effects of calcium antagonists in systemic hypertension. Am J Cardiol 79: 39-46.

25. Morgan T, Anderson A (2002) Comparison of candesartan, felodipine, and their combination in the treatment of elderly patients with systolic hypertension. Am J Hypertens 15: 544-549.

26. Morimoto S, Ogibara T (1994) TCV-116: A new angiotensin n type-1 receptor antagonist. Cardiovasc Drug Rev 12: 153-164.

27. Muller JE (1999) Circadian variation in cardiovascular events. AM J Hypertens 12: $355-425$

28. Nalbantgil I, Onder R, Kiliccioglu B, Turkoglu C (1993) Combination therapy with verapamil and nitrendipine in patients with hypertension. $\mathrm{J}$ Hum Hypertens 7: 305-308.

29. Nalbantgil I, Onder R, Nalbantgil S (1996) Sustained-release verapamil and trandolapril, alone and in combination, in the treatment of obese hypertensive patients: A double-blind pilot study. Curr Ther Res Clin Exp 57: 990-997.

30. Nalbantgil S, Nalbantgil I, O" nder R (2000) Clinically additive effect between doxazosin and amlodipine in the treatment of essential hypertension. Am J Hypertens 13: 921-926

31. Neutel JM (1999) Low-dose antihypertensive combination therapy: Its rationale and role in cardiovascular risk management. Am J Hypertens 12: 73-79.

32. Nishikawa K, Naka T, Chatani F, Yoshimura Y (1997) Candesartan cilexetil: A review of its preclinical pharmacology. J Human Hypertens 11: 9-17.

33. O'Brien ET, MacKinnon J (1972) Propranolol and polythiazide in the treatment of hypertension. Br Heart J 34: 1042-1044

34. Oparil S, Levine JH, Zuschke CA, Radman AH, Ripley E, et al. (1999) Effects of candesartan cilexetil in patients with severe systemic hypertension. Candesartan Cilexetil Study Investigators. Am J Cardiol 84: 289-293.

35. Opie LH, Messerli FH (2001) The choice of first-line therapy: Rationale for low-dose combinations of an angiotensin converting enzyme inhibitor and a diuretic. J Hypertens Suppl 19: S17-S21.

36. Philipp T, Letzel H, Arens HJ (1997) Dose-finding study of candesartan cilexetil plus hydrochlorothiazide in patients with mild to moderate hypertension. J Hum Hypertens 11:S67-S68.

37. Plouin PF (1997) Combination therapy with candesartan cilexetil plus hydrochlorothiazide in patients unresponsive to low-dose hydrochlorothiazide. J Hum Hypertens 11: S65-S66.

38. Prichard BN (1984) Combined alpha and beta receptor inhibition in the treatment of hypertension. Drugs 28: 51-68. 
Citation: Abib Jr E, Duarte LF, Oliveira L, Barros FP (2011) Evaluation of the Pharmacokinetic Interaction between Candesartan Cilexetil and Felodipine. J Bioequiv Availab 3: 005-010. doi:10.4172/jbb.1000049

39. Roca-Cusachs A, Torres F, Horas M (2001) Nitrendipine and enalapril combination therapy in mild to moderate hypertension: Assessment of doseresponse relationship by a clinical trial of factorial design. J Cardiovasc Pharmacol 38: 840-849.

40. Saltiel E, Ellrodt AG, Monk JP Langley MS (1988) Felodipine. A Review of its pharmacodynamic and pharmacokinetic properties, and therapeutic use in hypertension. Drugs 36: $387-428$.

41. Sanem N, Mehdi Z, Filiz O, Bahar B, Istemi N, Remzi O, Mustafa A (2003) Comparison of Candesartan and Felodipine Alone and Combined in the Treatment of Hypertension: A Single-Center, Double-Blind, Randomized, Crossover Trial. Current Therapeutic Research 64: 380-388.

42. Schulman DS, Flores AR, Tugoen J Dianzumba S, Reichek N (1996) Antihypertensive treatment in hypertensive patients with normal left ventricular remodeling and improved diastolic function. Am J Cardiol 78: 56-60.

43. Sever PS, Poulter NR (1987) Calcium antagonists and diuretics as combined therapy. J Hypertens Suppl 5: S123-S126.

44. Shibouta Y, Inada Y, Oima M, Wada T, Noda M, et al. (1993) Pharmacological profile of a angiotensin II receptor antagonist, 2-ethoxy-I-[[2'-(IH-tetrazol-5-yl]biphenylhighly 4-yl]methyl]- IH-benzimidazoie-7-carboxylic acid (CV-11974) and its prodrug potent (+)-I-(cyciohexyioxycarbonyloxy)-ethyl-2-ethoxy-I-[[2'(IH-tetrazol5yl)biphenyland 4-yl]-methyl]-IH-benzimidazole-7-carboxylate (TCV-116]. Pharmacol Exp Ther long-acting 266: 114-120.

45. Siegl PKS, Kivlighn SD, Broten TP (1994) Pharmacology of angiotensin
II receptor antagonists: Comparison with renin inhibitors and angiotensinconverting enzyme inhibitors. Expert Opin Invest Drugs 3: 925-944.

46. Sleight $P$ (1994) Cardiac benefits of ACE inhibitors and calcium antagonists alone and in combination. J Cardiovasc Pharmacol 23: S39-S42.

47. Song H, Bao W, Wang H, An G, Feny J, et al. (2008) Effects of extended release felodipine on endothelial vasoactive substances in patients with essential hypertension. with essential hypertension. Clin Chem Lab Med 46: 393-395.

48. Timmermans PB, Wong PC, Chiu AT (1993) Angiotensin II receptors and angiotensin II receptor antagonists. Pharmacol Rev 45: 205-251.

49. Walton T, Symes LR (1993) Felodipine and isradipine: new calcium-channelblocking agents for the treatment of hypertension. Clin Pharm 12: 261-275.

50. Weir MR (1998) The rationale for combination versus single-entity therapy in hypertension. Am J Hypertens 11: 163-169.

51. Wingstrand K, Abrahamsson B, Edgar B (1990) Bioavailability from felodipine extended release tablets with deferent dissolution properties. Int J Pharm 60 : 151-156.

52. Yao R, Cheng X, Liao YH, Chen Y, Xie JJ, et al. (2008) Molecular mechanisms of felodipine suppressing atheroscelerosis in high-cholesteroldiet apolipoprotein E-knockout mice. J Cardiovasc Pharmacol 51: 188-195.

53. Yedinak KC, Lopez LM (1991) Felodipine: a new dihydropyridine calcium channel antagonist. DICP 25: 1193-1206. 